\title{
The Status Of Performance Appraisal At Christian Colleges And Universities: Preliminary Results
}

Forrest Flaniken, University of Central Florida, USA Rosa Cintrón, University of Central Florida, USA

\begin{abstract}
People are the lifeblood of colleges and universities. If there are no students, faculty, administrators, and staff, there cannot be a college or university. People are their primary resource, and the development of these people is their raison d'être. Due to the paramount importance of the people who are in higher education, it is essential to understand how well these personnel are performing in their roles and if they are fulfilling the responsibilities for which they were hired.
\end{abstract}

Keywords: Christian colleges and universities; sectarian postsecondary education; job performance; performance appraisal; staffing practices; higher education; evaluation methods

\section{INTRODUCTION}

$\mathrm{n}$ higher education the stereotypical notions of performance, assessment, and appraisal are most often applied to the students. However, another important question to be answered in the area of appraisal addresses the evaluation of the faculty, administrators, and staff of colleges and universities. These employees are hired to enable these institutions to help accomplish the goals for which the institutions have been established. A critical question deserving a thorough answer is whether or not the employees are, in fact, fulfilling the responsibilities and requirements of their positions. Do colleges and universities really know how well their employees are performing, and is this information being conveyed accurately and on a timely basis to their employees? Are there well-developed appraisal systems in place that are used on a consistent basis? This article addresses the status of performance appraisal at Christian colleges and universities in the U.S.

\section{LITERATURE REVIEW}

Colleges and universities have provided a variety of organizational data including retention and graduation rates, faculty workload studies, and job and career placement records (Heck et al., 2000). Assessing the performance of administrators may well provide needed and useful information about the performance of the university, but it may represent high stakes assessment of individuals. This means that measures of employee effectiveness could be tied to their promotion, salary increases, contract renewal, or retention. Academic administrators today are expected to deal with a variety of specialized issues including budgetary and fiscal matters, to be able to interact with various government agencies, courts, and trustees, and have skills in public relations. The administrator is also expected to have skills in management, human relations, budget analysis, and strategic planning. Austin and Gamson (1983) refer to the new breed of academic administrator as a politician, a zoo keeper, an entrepreneur, and a machine operator because of the wide variety of skills and experience he or she needs to be successful (p. 55).

College administrators have embraced the systems and procedures of business and public relations professionals. They manage by objectives, form marketing groups, and use terminology from the business world such as cost-benefit analysis, market share, and investment opportunity. They have the skills necessary to deal successfully with newspaper editors, elected officials, budget administrators, alumni, and faculty leaders (Seldin, 1988). 
There has been recognition that colleges and universities have become something more than a group of educators and that these institutions can benefit from the same management standards that are used by for-profit organizations. Deans, for example, "today oversee professional organizations (colleges) that are in some ways similar to large professional partnerships or organizations in the private sector, such as those found in law and accounting firms" (Wolverton, Gmelch, Montez, \& Nies, 2001, p. 106). Keller (1983) has noted that "more and more, academic leaders are beginning to sense that unless their campuses have some solid, rational management they may not make it through the next decade, or may not pass through the period without wounds and distentions" (p. 57).

To ensure adequate competency in these areas, colleges and universities are giving closer attention to the administrators' abilities, competencies, and effectiveness. These institutions realize that evaluating and developing administrative performance can bring about positive change.

\section{Faculty Performance Appraisal in Higher Education}

It is helpful to briefly consider some of the issues related to faculty appraisal because faculty appraisal has had an influence on the acceptance and use of performance appraisal of staff at colleges and universities. The appraisal of faculty has a lengthy history, unlike the appraisal of staff which is relatively brief, but there has always been a degree of controversy that has surrounded it (Braskamp \& Ory, 1994). Faculty and administrators have not always seen appraisal as a good use of time, although it is a needed one. Its usefulness continues to be one of the most debatable and sensitive issues on campuses. Also, faculty give varying credibility to the appraisal of the different facets of their work. Research productivity is considered the easiest to measure equitably, while measuring teaching effectiveness and the quality of professional service is often not judged at all.

However, while faculty are more willing to support the assessment of their research compared to the assessment of their teaching or service activities, they do have some concerns with the current evaluation methods. Boyer (1990, p. 34) argues that "the full range of faculty talent must be more creatively assessed. It is unacceptable, we believe, to go on using research and publication as the primary criterion for tenure and promotion when other educational obligations are required." He goes on to note that many faculty are displeased with the current appraisal procedures because they "restrict faculty, distort institutional priorities, and neglect the needs of the students" (p. $35)$.

Part of the controversy surrounding the appraisal of faculty is the lack of a clear definition of exactly what the work of the faculty consists of and what is being evaluated. Clarity is needed in defining the work of the faculty before it can be measured. The following section addresses the issues that deal with identifying the work of the faculty, which then helps define what will be assessed.

\section{The Work of Faculty}

A three-part classification of the work of faculty that is very common includes research, teaching, and service (Clement \& Stevens, 1989; Dilts, Haber, \& Bialik, 1994). Braskamp and Ory (1994) use an expanded fourpart categorization which includes teaching, research and creative activity, practice and professional service, and citizenship. A brief description of each of these four categories follows.

Teaching includes classroom instruction, conducting laboratories, coaching interns and graduate students, and advising students in areas including which classes to take and career opportunities in their field of study. There is importance attached to creating a learning environment that enhances student learning opportunities and motivates student learning. The academic environment should emphasize cooperation and working together rather than competition, and high standards of excellence rather than ranking students against each other.

Research and creative activity include the various forms of discovering and integrating knowledge, critical analyses, and visual art performances. In this category, the creative arts are given comparable status to research activity because the amount of ingenuity and discipline required in the creative arts is similar to what engineers or scientists incorporate in their work. In the category of research and creative activity, the scholarship of discovery is 
critical because without new discoveries and insights, there would be little need for teaching and providing service to the community. Society has given colleges and universities the responsibility to search for and discover new knowledge for its own sake. The scholarship of integration, as defined by Boyer (1990, p. 18), is "making connections across the disciplines, placing the specialties in larger context, illuminating data in a revealing way, often educating nonspecialists, too." The scholarship of discovery and the scholarship of integration cannot be completely separated because the established disciplines have common concepts and knowledge bases.

The third of the four-part categorization of the work of faculty is practice and professional service. This focuses on solving the problems of society using the knowledge, expertise and professional judgment of the faculty, and it can include such things as public service, service to the university, outreach, application of knowledge, and practice. The emphasis is on the significant value of knowledge and the connection between colleges and universities and society. Braskamp and Ory (1994, p. 48) describe one purpose of a college or university "is to encourage faculty to become more involved in knowledge-linking."

The fourth part included in the work of faculty is citizenship which Braskamp and Ory (1994) put in a separate category to highlight its importance in faculty life and work. It is reflected in many types of faculty work and can be divided into three forms: institutional contributions that facilitate and promote the growth and advancement of the institution, disciplinary and professional contributions include participation in professional, scholarly, and disciplinary associations and organizations, private and community contributions that occur outside of one's professional and institutional life. This could include participation in civic, political, or religious organizations, holding public office, and providing free health care services to citizens. The determination of which of these criteria will be used by the institution to measure the performance of faculty should be dependent upon the mission and goals of the institution and its various subunits including its colleges, departments, and units (Dilts, Haber, \& Bialik, 1994). When an institution is able to clearly convey to its faculty which of these aspects of their work it considers important, and thus will be evaluated by the institution, it increases the credibility and usefulness of appraisal as an effective management and motivational tool.

When there is not clear communication and correlation of institutional goals with individual faculty goals, this causes faculty dissatisfaction and frustration with the appraisal process which then diminishes its credibility and usefulness. If, for example, the mission statement of a college states that it is a teaching institution, but then there are minimal efforts made to evaluate teaching, the credibility of the mission statement is lost. If the school in reality primarily rewards only research, then only research will be produced (Dilts et al., 1994).

\section{Goals of Faculty Appraisal}

To conclude this section on faculty performance appraisal, five goals of faculty appraisal (Braskamp \& Ory, 1994) will be reviewed. These goals will be compared to goals of performance appraisal as defined elsewhere in performance appraisal literature (for businesses, non-profits, and administrative staff at colleges and universities), and significant similarities or differences will be noted:

1. Address both individual and institutional goals: An effective institution simultaneously encourages the growth of its individual faculty and fulfills its own institutional goals. For faculty, professional growth necessitates learning and developing from one's own experiences which suggests the use of evaluation and feedback. This also includes having autonomy, freedom, and an organizational culture where experimentation is allowed along with some dead ends and failure. Likewise, institutions exist for a purpose and they must also be held responsible and accountable to their stakeholders for achieving their collective goals. A paradox exists between giving faculty their independence and monitoring their work, and while this paradox may never be resolved, it must be acknowledged and confronted. Job satisfaction and commitment come when employees know what is important to the organization and what its priorities are. Appraisal system goals should be clear and simple, and should be linked to the evaluation of performance, the establishing of objectives, and the identification of faculty development needs which take into account the institutions' goals (Smith, 1996). Appraisal is one means of communicating these goals to the faculty. 
2. Reflect the complexity of faculty work: Because faculty work is complex, the appraisal of the work should match the complexity of the work. The number of publications or a single score on a rating form do not sufficiently measure the contributions of faculty. A broad collection of appraisal methods is needed to best measure the work of faculty.

3. Foster faculty members' uniqueness and promote career development: Assessment of faculty work should reflect the individuality of the faculty, who are diverse in their goals, talents, and achievements, but not necessarily their individualism. The practice of appraisal should be carried out for the documentation for promotion, tenure, and salary increases, as well as for a means of improvement for the faculty member. Clement and Stevens (1989) suggest that the appraisal process should allow faculty members to take advantage of their individual strengths in meeting the goals of their respective departments.

4. Clearly communicate institutional goals and expectations: Feedback from appraisal can be a powerful means of socialization in which faculty can learn of the goals and expectations of the institution. Feedback during the appraisal process can be an effective way to promote and reward loyalty to an institution and to foster a sense of belonging, which some faculty particularly value.

5. Promote collegiality: Braskamp and Ory (1994) suggest that while faculty have long been involved in assessing the research of their colleagues, they have done little in the area of assessing teaching effectiveness and professional service. This is due to the public nature of research and the value that is placed on the different categories of work. While faculty autonomy is part of the culture, faculty can reclaim their accountability to their colleagues and thus reclaim the collegial tradition. Overall, if a college or university desires to support the career development of its faculty while at the same time meeting the broad goals of the institution, it must evaluate the work of its faculty from both an individual and an institutional perspective.

It is interesting to compare the goals of performance appraisal, reviewed earlier in this study that are applicable for most types of organizations, with those goals listed above that are specific for faculty appraisal. There is much similarity of goals including providing feedback to employees, encouraging performance improvement, determining developmental goals for employees, and providing information for personnel decisions such as pay increases and promotions. An interesting difference is that for faculty appraisal, there is significantly more emphasis placed on the input of the faculty, their career aspirations, and their individual developmental needs than was mentioned for most types of organizations. This can probably be attributed to the historically collegial nature of colleges and universities that has been characterized by faculty autonomy and independence.

\section{Organizational Governance and Performance Appraisal in Higher Education}

\section{Distinctive Characteristics}

Baldridge et al. (1977) suggest five distinctive characteristics of colleges and universities. The first is goal ambiguity. Most organizations have established goals, and they set strategies and processes to help them accomplish their goals. For example, businesses must make a profit, government firms follow the policies and guidelines set by the laws that created them, hospitals aim to heal sick people, and prisons try to rehabilitate. In contrast, colleges and universities have less clear goals and the list of goals might include teaching, research, community service, providing solutions to social problems, or supporting the arts. Cohen and March (1974) suggest that efforts to establish goals by institutions of higher education "produce goals that are either meaningless or dubious" (p. 195). Weber (2005) claimed that "while every one of the more than 3,000 colleges and universities in the United States has a mission statement that sets out its goals and objectives, those are invariably, and appropriately, vague and almost impossible to measure in objective fashion" (p. 41). Academic goals can be not only unclear but also highly contested (Baldridge et al.). As long as the goals are left unclear and ambiguous, they are easily agreed upon, but when they are made more concrete and actually implemented, conflict begins.

A second distinctive characteristic is that colleges and universities have clients who demand a voice in the decision-making process, similar to schools, hospitals, and welfare agencies. This can be a very significant and frequent factor in higher education where the clients are very capable of speaking for themselves. 
A third distinctive characteristic is having problematic technology due to serving clients with dissimilar, complex needs. Compared to manufacturing organizations whose work can more easily be segmented and made routine, in higher education it is more difficult to construct a simple technology that deals primarily with people and that relies heavily on professional expertise. If academic institutions are not always clear on what they are trying to accomplish, they also may not know how to do it well.

Baldridge et al. (1977) describe a fourth distinctive characteristic of colleges and universities as professionalism. Instead of an organization dividing a complicated task into smaller sets of routine procedures or tasks performed by unskilled and skilled employees, professional work requires that a broad range of tasks be completed by a single employee. These professionals typically demand autonomy in their work, wanting to be free from close supervision, and they tend to have divided loyalties between their own organization and their peers at the national level. There can also be tensions between professional staff and organization managers concerning ownership of responsibilities and decision-making authority. Also, professionals can demand peer evaluation of their work because they feel that only their colleagues are qualified to competently judge their performance.

The final distinctive characteristic that can separate colleges and universities from other organizations is environmental vulnerability (Baldridge et al., 1977). Although most organizations interact with their environments to some degree, some have more freedom than others in their actions. If the range of freedom is from high (in a typical business firm in a free market economy), to low (in public school districts that are constantly being watched by the communities they serve), colleges and universities are somewhere in the middle of the range. In recent years, however, colleges and universities have been subject to much more external review by the public, state legislatures, and the Federal government resulting in movement to less freedom. When there is increased external pressure from outside interest groups, the operating autonomy of the academic institutions is significantly decreased. Therefore, as their vulnerability grows, their governance structure changes extensively.

When summarizing the above five distinctive characteristics of colleges and universities and relating them to a specific organizational type, Baldridge et al. (1977) suggest that colleges and universities do not fit the standard category of "bureaucracy". Although bureaucracy does accurately describe certain parts of colleges and universities including the business operations, plant management, capital spending, and various auxiliary services, it does not adequately describe the heart of the institution which includes academic policy making, teaching, and research. Cohen and March (1974) suggest using the term "organized anarchy" to describe academic institutions which differs significantly from a bureaucracy or a collegium. The organized anarchy has generous resources that allow employees to go in various directions without coordination from a central authority. Leaders tend to be weak and there are many decisions made by individuals. Leaders tend to act more as catalysts and facilitators than decisionmakers, and negotiators rather than commanders. The image of organized anarchy helps capture the distinctive characteristics of colleges and institutions including unclear goals, problematic technology, and environmental vulnerability.

These distinctive characteristics of colleges and universities can have a significant influence on the use of performance appraisal. Performance appraisal depends greatly on the use of clearly stated goals, both for the individual and for the institution. If the goals are ambiguous, it is very difficult to define meaningful measurements for accomplishing them. If the goals are clear but highly contested, then it is more difficult to reach consensus on what goals will be used in the appraisal. The characteristics of professionalism and voice in the decision-making process suggest that the process of developing goals must be a joint effort in which both the person being appraised and the appraiser have input in the development of the goals. This will encourage ownership of the process by the person being appraised. The characteristic of environmental vulnerability, where colleges and universities are experiencing increasing accountability demands from outside interest groups, suggests that organizational freedom is decreasing and thus there will be a growing expectation of accountability. Performance appraisal is one tool used to help meet that demand.

\section{Organizational Governance}

Downey (1995), in his article "The University as Trinity: Balancing Corporation, Collegium, and Community", describes the university as consisting of three components - a corporation, a collegium, and a 
community - which has similarity to the three governance models mentioned above of bureaucracy, collegium and political system. He argues that each of the three components has elements which are critical to the idea of the university, but that each component also has elements that are not necessarily in harmony with each other. The value of the corporation component is that it provides an orderly environment where the business of the academic institution can be carried out. The corporation receives funding through various entities including the state, students, and donors without which the scholarly pursuits of the institution could not be carried out. If the institution is not well structured, financed, and managed, this will have a negative impact on its academic pursuits.

The second part of the trinity is the collegium which Downey (1995) suggests is essential to, but not the essence of, the academy. While the corporation works within a hierarchical authority, the collegium uses the principle of hieratic, or priestly, authority in which the faculty are given the highest power in matters pertaining to academic policy and principle. Within the collegium, democracy is practiced where faculty members may speak their minds in freedom such as raising objections and challenging any decisions made. Academic freedom resides in the collegium where individual faculty members are given the greatest reasonable amount of autonomy in the performance of their academic duties. The third component described by Downey is the community. Of all social institutions, he suggests that the university has the most attributes of a community including physical infrastructure of land, buildings, roads, sewers, and cultural and athletic facilities. It also includes personal, professional, social, recreational, and educational services, as well as a broad diversity of people with varying interests, competence, and ethnicities. Downey notes that neither the corporation nor the collegiums will thrive without such a community.

There has been a strong push in recent years towards the corporate emphasis and away from the collegium due to the demand for increased accountability from the constituents of academic institutions. If the trend continues in this direction, it would appear that the need for performance appraisal will only increase as one method for achieving stronger accountability.

Historically, a basic principle of higher education institutions has been that higher education is not a business, and thus concepts associated with a business-like corporation, such as hierarchical management of people, property, and profit are not appropriate for their organizations (Greenberg, 2004). Thus any mention on campus by the administration of a program losing money or that the faculty could be better managed in their responsibilities brings forth disparaging comments that the administration has a corporate mentality and is treating the institution as a business. This again raises the question concerning the appropriateness of using performance appraisal for the faculty, and certainly provides a forum for heated discussion and argument between faculty and administrators. Greenberg suggests there are clear reasons why higher education should be considered big business: (a) the ratings game and annual rankings between higher education institutions, (b) the close relationships between research universities and large businesses, (c) the semi-professional athletic programs, (d) multi-million dollar facilities, (e) faculty labor unions and strikes, (f) large salaries of college and university top administrators, and (g) the competition among schools to recruit students. He concludes by suggesting that if higher education institutions are going to lead the way forward, rather than being directed by outside constituents, they must think about their people, property, and productivity in business terms.

It is clear that the concept of performance appraisal fits more easily into a bureaucratic type of governance model than it does into the collegial model due to the reasons mentioned above. As colleges and universities continue to experience increased demand for accountability, and perhaps corresponding changes in their governance structures, it will be important to determine how and where accountability and appraisal best fit within this evolving structure.

\section{Religiously Affiliated Colleges and Universities}

According to the U.S. Department of Education, there are 2,578 private colleges and universities in the United States, of which 892 classify themselves as religiously affiliated (Snyder, Dillow, \& Hoffman, 2008). The religiously affiliated classification includes primarily Christian institutions (95\%) as well as other faiths such as the Jewish faith and the Mormon faith. The term "religiously affiliated" refers to key components of the institutions, including their articles of incorporation, by-laws, curricula, personnel, and a religious purpose and presence (Andringa, 2009). A large group of these institutions range from having full denominational ownership and control 
at one end of the spectrum to a remote, inactive historical affiliation on the other end. Other institutions are clearly faith driven but have no connection to a denomination. Religiously affiliated institutions are located in 45 states, have student bodies ranging from 100 to 30,000 students, have endowments ranging from $\$ 0$ to more than $\$ 500$ million, and offer varying degrees from associate and baccalaureate degrees only to doctoral degrees (Andringa, 2009).

The focus of this study is the 108 institutions in the United States that are members of the Council for Christian Colleges and Universities (CCCU). Christian colleges and universities have a unique opportunity to provide American society with a distinctive approach to higher education - an approach that is based upon and shaped by the Christian faith (DeJong, 1992). The success of these institutions in offering a unique educational model is significantly impacted by their ability to adopt and maintain their unique distinctives. DeJong divides the distinctives into two types - those relating to identity and those relating to the mission of the institution. Institutional identity is influenced by six components:

1. Private-Independent - This refers to the structure of the governing board of the institution. A private or independent institution is largely independent of government and political control and thus has more freedom in setting its distinctive educational identity.

2. Denominational Affiliation - Many Christian colleges and universities are affiliated with a church denomination which identifies the religious tradition that the institution is aligned with. This affiliation allows prospective students and the general public to draw conclusions about the nature of the institution and its theological viewpoints.

3. Residential Environment - Most of these institutions are residential in nature, with many of their students living on campus. This gives the institutions an opportunity to provide their students with a supportive campus community that shows concern for the students' normative development as a person, a learner, a worshiper, and a community member.

4. Behavioral Standards - Most church-related institutions have some type of behavioral standards that are derived from their religious traditions. These standards convey a sense of institutional identity and expectations for campus life.

5. Integration of Faith and Learning - Faculty and students are encouraged to integrate learning with their religious ideologies so that they are linked together rather than being compartmentalized as separate dimensions of their lives.

6. Emphasis on Teaching - The emphasis on the integration of faith and learning is closely related to an emphasis on teaching. While most of these institutions are involved in some research, their primary focus is on preparing students for leadership in all walks of life.

These six components of an institution's identity allow the institution to shape and communicate its unique identity and to form its institutional ethos.

The second type of distinctive that DeJong (1992) describes as impacting the unique organizational model of Christian colleges and universities is its institutional mission. The mission of the Christian institution separates it from other institutions by shaping its organizational life and guiding its day-to-day activities. DeJong describes four components that separate the mission of Christian institutions from other types of institutions.

1. Meaning and Value - The mission of a Christian institution is anchored in an expression of its Christian faith and grounded in a Christian view of reality. The entire educational experience is grounded in the Christian faith of the institution.

2. Intellectual Growth - While the overall mission of the institution is to foster intellectual growth, this is accomplished through a Christian point of view. Academic excellence includes the cultivation of a Christian point of view relating to the subject matter, the learning process, and everyday living.

3. Social, Physical, and Spiritual Development - The institutional mission includes not just intellectual growth but also the social, physical, and spiritual development of the student.

4. Responsible Citizenship - Part of the emphasis of integrating faith and learning includes teaching ethical responsibility in the academic disciplines as well as in the ethical issues of society. Community service is also a component of citizenship and is based on the Christian precept of loving one's neighbors. Another 
component of being a responsible citizen is to respect the physical environment and to avoid exploiting the Earth's resources and polluting the environment.

The contribution of Christian colleges and universities to higher education lies in their ability to develop unique identities and missions through these distinctives (DeJong, 1992).

\section{Governance, Freedom, and Accountability in Christian Institutions}

Christian colleges and universities are confronted with the same issues that all colleges and universities are confronted with including difficult economic limitations, greater degrees of accountability, and measurement of educational results (Greenberg, 2004). They are looking for ways to deal with financial, environmental, and managerial challenges while dealing with changes in student career interests and educational needs as well as competition from other educational institutions.

These Christian institutions may also face another challenge associated with their partnership with an ecclesiastical or a faith tradition. This challenge is the tension between freedom and accountability (Forest \& Kinser, 2002). On the one hand, faculty and students are encouraged to pursue truth with no hindrance of a priori assumptions. Ideas, theories, artifacts, and experiences are to be explored and discovered without restraint. On the other hand, the faith institutions argue that learning and the pursuit of knowledge are shaped by underlying beliefs and values, including those held by their faith tradition. Some scholars have argued that the purposes of Christian institutions are necessarily narrow and restrictive. This places doctrinal limits on scholarly inquiry which then lead to objectionable compromises of the principles of academic freedom (Sandin, 1992). However, in its pure form, the Christian college and university is not dogmatic but rather is open to all truth. Forest and Kinser (2002, p. 155) suggest that the students and faculty of the Christian institutions proceed through the educational process with their worldviews in place and actively engage in the learning process through those worldviews. This is not a form of dogmatism but rather clearly acknowledging and defining their own assumptions by virtue of the tenants of their faith.

\section{SUMMARY}

The use of performance appraisal can be traced back to China in the third century A.D., and from there it can be found in Ireland in the 1600s, in Scotland in the 1800s, and in the U.S. in the early 1800s. The U.S. government required the use of performance appraisal for all federal employees in 1978, and it became an established management tool in many organizations in the U.S. by the early 1950s. The use of performance appraisal in higher education is a more recent occurrence and began receiving significant attention in the 1960s and 1970s when competition for scarce resources and a decrease in the public's trust in higher education resulted in colleges and universities being asked to prove their effectiveness and efficiency (Alexander, 2000). The stakeholders of colleges and universities began holding these institutions to higher levels of accountability, and performance appraisal was adopted by the institutions as a tool to help strengthen their accountability.

Much of the literature on performance appraisal suggests that performance appraisal is an inevitable element of organizational life and, if done well, it serves a very useful role in the overall success of the institution. However, the literature also indicates there are significant challenges associated with performance appraisal. When it is not done well, it can be a detriment to the success of the institution and its employees.

\section{RESULTS}

The purpose of this study was to determine the extent to which the colleges and universities that are members of the Council for Christian Colleges and Universities (CCCU) in the United States are using performance appraisal for their staff positions.

The population surveyed in this study consisted of the 108 colleges and universities that are members of the CCCU. The data were collected from the responding institutions during the months of June and July, 2009. A total of $90(83.3 \%)$ of the member institutions of the CCCU completed and returned the questionnaire to the researcher. 
Information concerning the size of the responding institutions, as measured by the size of the student body, is in Table 1 and as measured by the number of staff and administrators, in Table 2.

Table 1: Number of Students at Responding Institutions

How many total undergraduate and graduate students does your institution have?

\begin{tabular}{lcc} 
Answer Options & Response \% & Response Count \\
\hline Less than 1,000 students & $21.6 \%$ & 19 \\
Between 1,000 and 2,000 students & $35.2 \%$ & 31 \\
Between 2,000 and 3,000 students & $21.6 \%$ & 19 \\
More than 3,000 students & $21.6 \%$ & 19 \\
answered question & & 88 \\
\hline
\end{tabular}

Note: Two institutions did not respond to this question.

Table 2: Number of Staff and Administrators at Responding Institutions

How many staff and administrators (i.e. all employees excluding faculty) does your institution have?

\begin{tabular}{lcc} 
Answer Options & Response \% & Response Count \\
\hline Less than 200 & $40.9 \%$ & 36 \\
Between 200 and 600 & $54.5 \%$ & 48 \\
Between 600 and 1,000 & $4.5 \%$ & 4 \\
More than 1,000 & $0.0 \%$ & 0 \\
answered question & & 88 \\
\hline
\end{tabular}

Note: Two institutions did not respond to this question.

Table 3 presents the data regarding the use of performance appraisal for the evaluation or development of staff positions at these institutions. The data indicate that of the 90 institutions that responded to the questionnaire, $84.4 \%$ (76 of the institutions) used a performance appraisal system for their staff positions.

Table 3: Use of Performance Appraisal for Staff Positions

Does your institution use a performance appraisal system for the evaluation or development of its staff positions?

\begin{tabular}{lcc} 
Answer Options & Response \% & Response Count \\
\hline Yes & $84.4 \%$ & 76 \\
No & $15.6 \%$ & 14 \\
answered question & & 90 \\
\hline
\end{tabular}

For the 76 institutions that used a performance appraisal system, Table 4 provides data indicating how long they had used performance appraisal for their staff. The majority of institutions $(71.1 \%)$ had used performance appraisal for staff for more than six years, while $17.1 \%$ of the institutions had used performance appraisal for one to three years, and $10.5 \%$ for four to six years.

Table 4: Length of Time that Performance Appraisal Has Been Used How long has your institution used a performance appraisal system?

\begin{tabular}{lcc} 
Answer Options & Response \% & Response Count \\
\hline Less than 1 year & $1.3 \%$ & 1 \\
1 - 3 years & $17.1 \%$ & 13 \\
4 - 6 years & $10.5 \%$ & 8 \\
More than 6 years & $71.1 \%$ & 54 \\
answered question & & 76 \\
\hline
\end{tabular}

Note: Only 76 institutions use performance appraisal systems. 
When asked what kind of performance appraisal system their school used, 98.7\% (75 of 76) responded that they used a manual system using either a word-processing program or a paper system, while only one school used a software program written specifically to do performance appraisal. The data are summarized in Table 5. The one institution that used a software program written specifically for performance appraisal used a program purchased from a software vendor rather than written and developed internally by the institution.

Table 5: Type of Performance Appraisal System Used

Which of the following best describes the type of performance appraisal system that your institution uses?

\begin{tabular}{lcc} 
Answer Options & Response \% & Response Count \\
\hline $\begin{array}{l}\text { A manual system using either a word-processing program (e.g. } \\
\text { Microsoft Word) or a paper system. }\end{array}$ & $98.7 \%$ & 75 \\
A software program written specifically to do performance & $1.3 \%$ & 1 \\
appraisals. \\
answered question
\end{tabular}

Note: Only 76 institutions use performance appraisal systems.

Table 6 provides a summary of the responses to the question asking how performance appraisal was used by each institution. Most institutions (89.5\%) used performance appraisals both to review past performance and to improve the effectiveness of the employees, while $6.6 \%$ used performance appraisals to only review past performance and $3.9 \%$ used performance appraisals to only improve the effectiveness of employees.

Table 6: Description of How Performance Appraisal is Used In your institution, performance appraisals are used primarily to (please check only one box):

\begin{tabular}{lcc} 
Answer Options & Response \% & Response Count \\
\hline Review past performance & $6.6 \%$ & 5 \\
$\begin{array}{l}\text { Improve the effectiveness of the employees } \\
\text { Both review past performance and improve the effectiveness of the }\end{array}$ & $3.9 \%$ & 3 \\
employees & $89.5 \%$ & 68 \\
answered question & & 76 \\
\hline
\end{tabular}

For those institutions that used performance appraisals for their staff, $90.8 \%$ (69 of 76) administered performance appraisals once a year, while only one school administered performance appraisals every six months. Six schools provided additional responses, including using an annual appraisal process after an initial 90-day review was completed at the beginning of employment, or giving two reviews in the first year and then an annual review thereafter. These schools were effectively giving annual reviews after the initial start-up period (see Table 7).

Table 7: Frequency of Receiving a Formal, Written Performance Appraisal How often do most employees receive formal, written performance appraisals from their supervisors?

\begin{tabular}{lcc} 
Answer Options & Response \% & Response Count \\
\hline Once a month & $0.0 \%$ & 0 \\
Once a quarter & $0.0 \%$ & 0 \\
Once every 6 months & $1.3 \%$ & 1 \\
Once a year & $90.8 \%$ & 69 \\
Other (please specify) & $7.9 \%$ & 6 \\
answered question & & 76 \\
\hline
\end{tabular}

The final question in the questionnaire allowed the respondents to comment or elaborate on any of the issues addressed in the questionnaire that would complement the research study. Of the 90 respondents to the questionnaire, 25 respondents provided comments to the open-ended question. This section will highlight some of the more significant themes that were noted. 
There were four responses that indicated the institution had either recently strengthened or was planning to strengthen its performance planning process in the future. Their comments included:

1. "am in process of assessing our current performance management system - and plan to implement a new system more aligned $\mathrm{w} /$ organizational goals, performance goals, and behavioral competencies."

2. "We are in the process of moving toward a new approach to performance appraisal. We have had a campus-wide task force evaluating content and structure, and selecting a software product. We hope to implement a new process over the next academic year."

3. " "This is our first year for the PMP."

4. "We have new performance appraisal system that was begun just last summer (2008). Top level support is still more lip service than by example, but it is more support than previously given. Extensive training was provided. A task force of administrators and staff and HR designed the new process and form. It is well liked by those that have used it already."

There were four institutions who indicated that their performance appraisal system needed improvement. The comments included:

1. "Because our appraisal process is merely evaluative and not necessarily tied to performance management, it lacks effectiveness. It needs an overhaul; however, this would require time and resources that are not currently available and I'm not sure if managers and supervisors are willing to commit the time to accomplish this."

2. "Human Resources would like to revise the forms used at our institution."

3. "Our P/A system and compliance is very poor, and is high on our radar to improve soon!"

4. "I have wanted to revise our appraisal tool during my nearly two years at the institution but other pressing needs have pushed it lower on the priority scale."

There was frustration voiced by several respondents concerning the lack of support for their performance appraisal system by their administrators and staff:

1. "Evaluation forms are sent out for every position every year; something less than half are returned ...I now send the VPs quarterly reports showing evaluations completed, which has also increased the number returned, but not above half. I dislike the process, and I think employees do too, because it isn't applied uniformly. I send all the forms out, but have been evaluated myself only once in 19 years."

2. "We have a performance appraisal system in place - most managers do not enjoy completing the forms and as such, most are delinquent and even sometimes missed completely. The appraisals are not tied to salary increases or job promotion. It seems as though it's simply an exercise that takes up time. I struggle with trying to get managers to complete the forms. Sigh...frustrating."

3. "This institution lacks a standardized campus-wide performance appraisal system. Many employees do not even receive evaluations and nobody is held accountable for not providing them. As our institution lacks an HR department, there is no one to oversee these kinds of issues, which is detrimental to employees and in turn the institution as a whole."

4. "At present, consistency varies widely in our institution with some departments adhering to a regular performance appraisal schedule and other departments avoiding the process. Our goal is to create a campus-wide structure and system of accountability to improve this."

\section{AUTHOR INFORMATION}

Dr. Forrest Flaniken serves as Senior Vice President for Wycliffe Bible Translators in Orlando, FL. He has held various positions with Wycliffe including Chief Financial Officer and Vice President for Operations.

Prior to joining Wycliffe, Forrest worked with three manufacturing companies in roles including Controller, Chief Financial Officer, and Director of Finance and Administration. Forrest is also an adjunct professor at Palm Beach Atlantic University where he has taught for eight years. His educational background includes a B.A. in Economics from Davidson College, an MBA from Vanderbilt University, and a doctorate in Educational Leadership from the University of Central Florida. He can be reached at Forrest_Flaniken@wycliffe.org 
Dr. Rosa Cintron is an associate professor at the University of Central Florida. She teaches in the program of Higher Education \& Policy Studies at the master's and doctoral level. Her research interests are in the areas of access and social justice in postsecondary education. She received her doctoral degree from Florida State University. She can be reached at: rcintron@mail.ucf.edu

\section{REFERENCES}

1. Alexander, F. K. (2000). The changing face of accountability. Journal of Higher Education, 71(4), 411431.

2. Andringa, R. C. (2009). Keeping the faith: Leadership challenges unique to religiously affiliated colleges and universities. In J. Martin \& J. E. Samels (Eds.), Turnaround: Leading stressed colleges and universities to excellence (pp. 168-184). Baltimore: Johns Hopkins University Press.

3. Austin, A. E., \& Gamson, Z. F. (1983). Academic workplace: New demands, heightened tensions. ASHEERIC Higher Education Research Report No. 10. Washington, DC.: Association for the Study of Higher Education.

4. Baldridge, J. V., Curtis, D. V., Ecker, G. P., \& Riley, G. L. (1977). Alternative models of governance in higher education. In G. L. Riley \& J. V. Baldridge (Eds.), Governing academic organizations: New problems, new perspectives (pp. 1-347). Berkley, CA: McCutchan Pub. Corp.

5. Boyer, E. L. (1990). Scholarship reconsidered: Priorities of the professoriate. Princeton, NJ: Carnegie Foundation for the Advancement of Teaching.

6. Braskamp, L. A., \& Ory, J. C. (1994). Assessing faculty work: Enhancing individual and institutional performance (1st ed.). San Francisco: Jossey-Bass Publishers.

7. Clement, R. W., \& Stevens, G. E. (1989). Performance appraisal in higher education: Comparing department of management with other business units. Public Personnel Management, 18(3), 263-78.

8. Cohen, M. D., \& March, J. G. (1974). Leadership and ambiguity: The American college president. New York: McGraw-Hill.

9. DeJong, J. (1992). Making sense of church-related higher education. New Directions for Higher Education, 79, $19-27$.

10. Dilts, D. A., Haber, L. J., \& Bialik, D. (1994). Assessing what professors do: An introduction to academic performance appraisal in higher education. Westport, Conn.: Greenwood Press.

11. Downey, J. (1995). The university as trinity: Balancing corporation, collegium, and community. Innovative Higher Education, 21(2), 73.

12. Forest, J. J. F., \& Kinser, K. (2002). Higher education in the United States: An encyclopedia. Santa Barbara, Calif.: ABC-CLIO.

13. Greenberg, M. (2004). A university is not a business (and other fantasies). Educause Review, 39(2), 10-16.

14. Heck, R. H., Johnsrud, L. K., \& Rosser, V. J. (2000). Administrative effectiveness in higher education: Improving assessment procedures. Research in Higher Education, 41(6), 663-684.

15. Keller, G. (1983). Academic strategy: The management revolution in American higher education. Baltimore, Md.: Johns Hopkins University Press.

16. Sandin, R. T. (1992). To those who teach at Christian colleges. New Directions for Higher Education, 79, 43-54.

17. Seldin, P. (1988). Evaluating and developing administrative performance: A practical guide for academic leaders (1st ed.). San Francisco: Jossey-Bass.

18. Smith, R. (1996). Staff appraisal at Nene College of Higher Education. Higher Education Management, 8(2), 69-77.

19. Snyder, T. D., Dillow, S. A. \& Hoffman, C. M. (2008). Digest of education statistics, 2007.Downloaded March 13, 2009 from http://nces.ed.gov/pubsearch/pubsinfo.asp?pubid=2008022

20. Weber, J. C. (2005). Why can't colleges and universities be run more like businesses? College and University, 80(3), 39-42.

21. Wolverton, M., Gmelch, W. H., Montez, J., \& Nies, C. T. (2001). The changing nature of the academic deanship. Washington, DC.: ERIC Clearinghouse on Higher Education. 